\title{
Genetic safety in Russia: threats and legal regulation perspectives
}

\author{
Vyacheslav Borisovich Evdokimov and Emil Vaizovich Alimov* \\ Institute of Legislation and Comparative Law, Department of Constitutional Law, 117218 Moscow, Russia
}

\begin{abstract}
The article provides a general theoretical and legal analysis of a little-studied legal category genetic safety. Based on the study of the Russian and foreign scientific literature and a number of legal acts, the authors identified the main threats to genetic safety and pointed out specific issues requiring detailed analysis and legal assessment. In particular, the authors consider the results of genetic testing in the armed forces (shown using the experience of the United States). The authors came to the conclusion that at present Russia is significantly lagging behind the advanced foreign states in the genetic safety legal regulation. This is confirmed by the lack of relevant laws and the documents of organizations carrying out this activity (the so-called "self-regulation"). It seems that the positive experience of genetic safety regulation issues in leading foreign countries can be used to improve the regulatory framework in the Russian Federation.
\end{abstract}

\section{Introduction}

Modern genetic research is opening up previously unavailable opportunities for society in terms of disease prevention and treatment, the development of new methods of clinical diagnosis, epidemic control, family planning, bioengineering, and many other areas of public relations $[1,2]$.

The continuous development of social relations entails the need for constant legal regulation improvement, so that it corresponds to the realities prevailing in society. This statement is also true for the conducting genetic research procedure, since this relatively new area of public relations unites both public and private interests. In this regard, legal regulation should take into account such principles as: balance of public and private interests, protection of human rights and freedoms, protection of secrets protected by law, ensuring national interests, etc.

Leading foreign states are actively developing a system of normative legal acts regulating various issues of genetic research [3]. So, in the United States, such issues as the prohibition of discrimination, medical insurance, confidentiality of personal information, newborn screening, certain types of clinical and scientific research, etc. have received legal regulation. In particular, in 2008 the United States passed the Genetic Information Non-discrimination Act.

UK Data Protection Act 1998 currently in force contains a number of regulations in the field of protection and processing of information obtained as a result of genetic research. For example, for research purposes, editing the human genome is prohibited if the genes being edited can be inherited.
In foreign countries, genetic research safety issues are currently being actively developed. At the same time, the main attention of the authorities is directed to the issues of preserving personal information, the inadmissibility of genetic discrimination and the products obtained using genetically modified organisms certification procedure [4]. However, the genetics dynamic development (in fact, in real time), in addition to the new opportunities and innovations, also carries certain risks that have yet to be analyzed by scientists and specialists in order to ensure the safety of society, the state and the individual.

At present Russia is significantly lagging behind the advanced foreign states in the genetic safety legal regulation. This is confirmed by the lack of relevant laws and the documents of organizations carrying out this activity (the so-called "self-regulation").

\section{Genetic research legal regulation}

Speaking about the Russian experience in the legal regulation of the genetic research organization and conduct, it should be noted that in general this area has received fragmentary legal regulation. It comes down mainly to issues of state genetic registration (Federal Law of December 3, 2008 No. 242-FZ «On State Genomic Registration in the Russian Federation»). They also include genetic engineering (Federal Law of July 5, 1996 No. 86-FZ «On state regulation in the field of genetic engineering activity»). There is also genetic (genetic and molecular) examination (Article 79 of the Civil Procedure Code of the Russian Federation, paragraph 20 of the Resolution of the Plenum of the Supreme Court of the Russian Federation of May 16, 2017 No. 16 «On the application to the courts and 
legislation in cases involving the determination of the origin of children»).

Moreover, Federal Law of December 3, 2008 No. 242-FZ «On State Genomic Registration in the Russian Federation» defines the concept of «genomic information» as a type of personal data that includes encoded information about certain fragments of deoxyribonucleic acid of an individual or an unidentified corpse that do not characterize their physiological qualities. However, this concept is used only in the framework of the state genomic registration, and does not apply to other areas of the genetic information use, which is confirmed by the lack of relevant provisions in the legislation on personal data and law enforcement practice.

In Russian legal acts, as well as in judicial practice, human rights in genetic research are not defined, there are no necessary legal guarantees in this area, and the human genome is not currently considered an integral component of the right to protect health and medical care. In addition, in the Russian Federation the human genome is not the subject to civil rights; there are no special rules on criminal liability for criminal acts in the field of genetic research.

We noted the Federal Law of June 23, 2016 No. 180-FZ «On Biomedical Cellular Products». It is aimed at the development, preclinical research, clinical research, examination, state registration, production, quality control, storing, transporting, importing into the Russian Federation, exporting from the Russian Federation. This also includes destroying biomedical cellular products intended for prevention, diagnosis and treatment of diseases or conditions of the patient, pregnancy maintenance, and medical rehabilitation of the patient, as well as the relations arising in connection with the donation of biological material for the production of biomedical cell products.

At the same time, the enormous potential of genetic research makes it necessary to adopt an appropriate regulatory framework and government programs. In this regard, we should note:

- the Decree of the President of the Russian Federation dated December 1, 2016 No. 642 «On the Strategy for Scientific and Technological Development of the Russian Federation»;

- the Decree of the President of the Russian Federation dated June 6, 2019 No. 254 «On the Strategy for the Development of Health Care in the Russian Federation for the period until 2025»;

- the Decree of the President of the Russian Federation of November 28, 2018 No. 680 «On the Development of Genetic Technologies in the Russian Federation»;

- the Decree of the Government of the Russian Federation of April 22, 2019 No. 479 «On Approval of the Federal Scientific and Technical genetic technology development programs for 2019-2027».

The Strategy for Scientific and Technological Development of the Russian Federation provided for several areas of development for 2019-2027 based on the genetic technologies development, such as: biosafety and ensuring technological independence; genetic technologies for agricultural development; genetic technologies for medicine; genetic technologies for industrial microbiology. The section of the Strategy on the state of genetic technologies development in the Russian Federation provides information on the significant lag in the domestic sphere of genetic technologies from advanced foreign countries in scientific, regulatory, and applied aspects. It is also noted that in order to solve the problems of the genetic technologies development, it is necessary to create conditions for the formation of competitive scientific and (or) scientific and technical results. This includes an increase in the number of domestic laboratories and research centers implementing engineering approaches, to prepare highly qualified research teams, to develop and create equipment and information resources to ensure their effective operation.

Despite the general strategic nature, the Program for the Development of Genetic Technologies for 2019-2027 contains a number of controversial statements. For example, it is indicated that the development of genetic technologies, including genetic editing technologies, and their practical application are priorities in leading countries of the world. However, Convention for the Protection of Human Rights and Dignity of the Human Being with regard to the Application of Biology and Medicine, the Convention on Human Rights and Biomedicine (concluded in Oviedo on April 4, 1997), which is currently not ratified by the Russian Federation and several other states, provides for certain legal guarantees for patients.

In addition, in the mentioned Federal Program for the Development of Genetic Technologies for 20192027 , on the one hand, it is rightly concluded that genetic editing is a breakthrough tool that is already finding practical use in agriculture, industrial biotechnology, and medicine. On the other hand, Federal Law of July 3, 2016 No. 358-FZ «On Amending Certain Legislative Acts of the Russian Federation Regarding Improving State Regulation in the Field of Genetic Engineering» prohibited to import into the territory of the Russian Federation and to grow plants and animals whose genetic program has been modified using genetic engineering methods. There is an exception for those done in the course of examinations or scientific research, and developers of the genetically modified products are required to undergo the relevant registration procedures. In the circumstances, the federal legislator needs to give a legal assessment of the current situation, taking into account the latest achievements of science, in particular genetic engineering, and the positions of scientists and specialists in the field of genetics, biology and jurisprudence.

In Russia, a number of non-state companies carry out activities in the field of genetic research, primarily genetic testing. Companies on their official sites on the Internet indicate that genetic tests will allow you to: decrypt the human genome, learn about ancestors, get tips on playing sports, weight loss and nutritional advice, and warn about addictions to diseases. However, analysis of open information sources does not allow finding any self-regulatory documents of nongovernmental institutions, unlike state ones. We believe 
that this is due both to the weak level of development of these public relations in the country and to the lack of appropriate legislative regulation.

Based on the information above we can conclude that the legislation of the Russian Federation in the field of genetic research is at the initial stage, which is not surprising given the relative youth of this field of science. For the development of genetics, the noted federal strategic documents are adopted, which, most likely, will form the basis for further legislative regulation of genetic research in the Russian Federation.

The legal regulation of genetic research and genetics in general in Russia, according to the aforementioned and a number of other state documents, should receive an active impetus for development in the coming years. However, the unstable foreign policy situation is a risk and a big challenge for Russia, in particular, associated with some restrictions on the import of certain foreign products into Russia. This may negatively affect the noted plans for intensive progress in the field under consideration and, with a high degree of probability, will interfere with improvement of new research methods and practices for conducting genetic research in Russia.

\section{Genetic safety: common understanding and major threats}

In general, genetic safety, as a relatively new area of safety, is the genetic information protection from the unauthorized collection, storage, use and transfer to third parties for illegal purposes threats.

It should be noted that genetic safety is complex. So, in certain areas, it can be considered as a component of biological, environmental and food security. At the same time, genetic safety has its own specificity, which allows it to be considered as an independent type of safety. This is due to the fact that both the method of obtaining and using such information is unique, as well as the specifics of such personal information, which makes it possible to obtain a significant amount of information about a person and about his blood relatives [5]. In particular, this applies to the possibilities of fighting crime, personal identification, development of new technologies [6].

Based on the general analysis of Russian and foreign scientific literature, legal documents (including strategic planning documents), the main threats to genetic security should include:

1. Violation of human and civil rights and freedoms (inviolability of private life; individual dignity; obligatory consent of a person to conduct any medical, scientific or other experiments, etc.).

2. Violation of a personal, family, state and other secrets protected by law.

3. Use of genetic databases for the unauthorized and uncontrolled identification of citizens' purpose.

4. Genetically modified organisms use in various fields of activity (enshrined in the Concept of Biological Security of the CIS Member States of March 15, 2007 as a source of biological threats). It should be noted that, in contrast to the Russian (as well as many post-Soviet states) generally restrictive approach, many foreign states, on the contrary, actively support the use of GMOs in the agricultural and food sectors (for both import and export). It seems that it is necessary to conduct scientific research on this topic with the participation, first of all, of leading Russian geneticists and biologists.

5. Viruses Creation (biological weapons). This point is extremely controversial, since open sources present various geneticists, biologists, and statesmen's positions. 6. Challenging the dominant cultural, spiritual and moral ideas in the public consciousness through uncontrolled and unethical genetic research (editing the human embryo genome, human cloning).

To form a scientific and legal understanding of such a relatively new phenomenon as "genetic safety", each of the noted threats to genetic security requires a comprehensive scientific study to confirm their reality and significance.

\section{Genetic safety legal regulation}

Speaking about the genetic safety legal regulation, we should understand that in Russia this area of public relations is in the process of emergence. As noted earlier, there are only several normatively regulated issues: state genetic registration (Federal Law of December 3, 2008 No. 242-FZ "On the State Genetic Registration in the Russian Federation"). There is also genetic engineering (Federal Law of July 5, 1996, No. 86-FZ "On the State Regulation in the field of genetic engineering"), genetic (genetic-molecular) expertise (Article 79 of the Civil Procedure Code of the Russian Federation).

Some of the genetic safety issues are reflected in the framework of ensuring biological and food security. However, at the federal legal level, the topic of genetic safety has not been independently reflected, which, of course, does not contribute to the protection of national interests.

Accordingly, the importance of ensuring genetic safety determines the demand for the adoption of an appropriate legal framework, including strategic planning documents. In this regard, several decrees should be noted: Decree of the President of the Russian Federation of December 1, 2016 No. 642 "On the strategy of scientific and technological development of the Russian Federation". There is the Decree of the President of the Russian Federation dated March 11, 2019 No. 97 "On the foundations of the state policy of the Russian Federation in the field of chemical and biological safety for the period up to 2025 and beyond". The Decree of the President of the Russian Federation dated November 28, 2018 No. 680 is "On the development of genetic technologies in Russian Federation". So, for example, in paragraph 15 of the Decree of the President of the Russian Federation of March 11, 2019 No. 97 the main tasks of the state policy in the field of ensuring chemical and biological safety in terms of resource support for the national chemical and biological safety system also include the creation of conditions for the genetic certification of the population, 
the development of screening technologies for the gene pools of humans, animals and plants.

The tasks stipulated by the Strategy for Scientific and Technological Development of the Russian Federation determined such directions for the implementation of this Program for 2019-2027, based on the development of genetic technologies, such as biosafety and ensuring technological independence; genetic technologies for agricultural development; genetic technologies for medicine; genetic technologies for industrial microbiology. The section on the development of genetic technologies in the Russian Federation of the Program provides information on the significant lag of the domestic sphere of genetic technologies from advanced foreign countries both in scientific, legal and practical aspects.

There is a reasonable position according to which the main modern threats in the field of genetic information circulation facing Russia should include cost, unauthorized access, errors, mass screenings, irresponsible collection and irresponsible storage of genetic information [7]. Taking into account the fact that determining the position of one gene in the human genome can accurately identify one single person out of 10 billion other people, the genetic research implementation poses certain tasks in the field of personal data protection, privacy, medical, family and other secrets protected by law [8].

An interesting example is the use of genetic testing in the military activities. The most indicative is the experience of the United States, where such a procedure is actively used. So, all US military personnel must provide a DNA sample, which is used to identify their remains if they die in battle, as well as to identify a predisposition to cell anemia and G6PD (Glucose 6phosphate dehydrogenase) deficiency [9].

It is important to take into account the fact that the revealed predisposition to a certain disease does not guarantee its onset. Therefore, in the United States, such information does not mean automatic rejection of a candidate for military service or mandatory dismissal from military service. At the same time, the onset of such a disease in conjunction with a positive genetic test will be a legal basis for non-payment of benefits for a serviceman, if he does not prove that the onset of the disease was the result of unfavourable military service conditions [9]. The obtained genetic information is used to ensure the safety of such military personnel measures can be taken to prevent them from certain work or adverse environmental factors that can cause illness or aggravate health problems [9].

The main questions in terms of ensuring genetic safety are how genetic information can be used (for various commercial purposes, which can lead to discrimination against persons with certain genes; for the purpose of unauthorized identification of citizens; for editing the human genome, etc.) and what measures should be taken by the state to prevent such illegal activities [10].

A rare example of legislative activity in this area should be noted. Thus, draft law No. 744029-7 adopted by the State Duma in the first reading "On Amendments to Article 11 of the Federal Law" On Personal Data "regarding the processing of biometric personal data" will create the necessary legal basis for the implementation of the constitutional rights of citizens, protection of public and state interests, filling legislative gaps in the genetic personal data processing.

We believe that in order to develop genetic safety legal regulation it is necessary to study the following specific issues:

- expanding the circle of persons subject to mandatory state genetic registration;

- the admissibility of the genetic information collection about Russian citizens by foreign and (or) international organizations;

- obligatory state registration of non-state genetic databases;

- uniform standards and rules development for the collection, storage and use of genetic information about citizens by Russian commercial and non-commercial organizations;

- procedure for granting access to non-state genetic databases to relevant law enforcement agencies development;

- genetic information use in the military sphere (to military service admission and passage, the appointment of pensions to military personnel and members of their families, etc.);

- determination of acceptable moral and ethical boundaries for conducting scientific research of the human genome (editing the human genome, cloning a person, etc.);

- establishment of requirements for a comprehensive assessment (examination) of the genetic technologies safety;

- comprehensive scientific study of the harm to humans of products created using genetically modified organisms;

- study of biological weapon creation possibility based on the results of relevant genetic research.

\section{Conclusion}

The active use and development of genetic research can be instrumental in solving many socially significant problems in the field of family planning, predicting, preventing and treating many diseases, behavioural disorders, crimes investigation, significantly increasing the volume of food products, etc. At the same time, there are certain legal risks of abuse and harm to the interests of citizens, society and the state.

The high importance of genetic information contained in the DNA implies the need for the state to provide an effective mechanism for legal regulation that would ensure the protection of such information from unlawful collection, storage, use and transfer.

In the current conditions of a tense international situation, it is necessary to provide a legal mechanism to prevent actions aimed at gaining access to the genetic data of Russian citizens for illegal use.

It seems that the state should create the necessary conditions so that genetic information obtained through 
research or otherwise is protected from any unlawful interference. It is also necessary to take into account the experience of foreign countries and the provisions of generally recognized international standards [11].

\section{Acknowledgments}

The scientific research as supported by RFBR grants $\mathrm{N}$ 18-29-14100 and N 18-29-14009.

\section{References}

1. F.S. Collins, K.G. Jegalian, Deciphering the Code of Life, Scientific American, 281(6), 86-91 (1999)

2. T.G. Wolfsberg, I. Mcintyre, G.D. Schuler, Guide to the draft human genome, Nature, 409, 824-826 (2001)

3. S.B. Nanba, O.A. Akopyan, E.V. Alimov, M.A. Garmaeva, Z.N. Bedoeva, State Programs for the Development of Genetic Technologies, Opción, 26, 732-750 (2020)

4. E.V. Alimov, Genomic research legal regulation system: experience of Russia and the USA, RUDN Journal of Law, 23(4), 546-564 (2019)
5. M.A. Rothstein, B.M. Knoppers, H.L. Harrell, Comparative Approaches to Biobanks and Privacy, JLME, 44(1), 161-172 (2016)

6. V.Yu. Vladimirov, I.N. Gorbulinskaya, S.N. Kubitovich, The issue of genomic data security, Biosfera, 10(1), 42-47 (2018) (In Russ.)

7. A.B. Dubov, V.G. Dyakov, Genomic information security: legal aspects of international and national regulation, Courier of MSAL, 4, 127-137 (2019) (In Russ.)

8. Z. Lin, A.B. Owen, R.B. Altman, Genomic Research and Human Subject Privacy, Science, 305(5681), 183 (2004)

9. S. Baruch, K. Hudson, Civilian and Military Genetics: Nondiscrimination Policy in a Post-GINA World, AJHG, 83(4), 435-444 (2008)

10. N.G. Zhavoronkova, A.A. Mokhov, V.B. Agafonov, Legal challenges in minimizing the impact of past (accumulated) environmental damage on human health and the human genome, TSU JL, 38, 113-120 (2020) (In Russ.)

11. R. Branum, M.S. Wolf, International Policies on Sharing Genomic Research Results with Relatives: Approaches to Balancing Privacy with Access, JLME, 43(3), 576-593 (2015) 